УДК 371.388.3: 811.111

DOI: $10.35619 /$ iiu.v1i11.223

Kateryna Tretiakova

Candidate of Philological Sciences, Associate Professor, Associate Professor at Methodology of Foreign Languages Teaching Department, Rivne State University for the Humanities, Rivne, Ukraine ORCID: 0000-0001-6821-4652 e-mail:kmvim2012@gmail.com

Dmytro Bihunov Candidate of Psychological Sciences, Lecturer at Practice of English Language Department, Rivne State University for the Humanities Rivne, Ukraine ORCID: 0000-0001-6100-7765 e-mail: bihunov.d@gmail.com

\title{
NEW ELT METHODOLOGY CURRICULUM: STUDENTS' EXPECTATIONS OF SCHOOL PRACTICE
}

\begin{abstract}
Higher and secondary education institutions are in the intensive search for new strategies and approaches to encourage and motivate students for thorough and comprehensive study. Nowadays young people should be prepared to respond to any challenge so that they will be able to cope with their future roles, such as citizens, parents, teachers, and so on.

Therefore the new Pre-Service Teacher Training (PRESETT) Curriculum at Bachelor's level for trainee teachers of English has been created as a vital, urgent and necessary document which can lead to the new educational policy. Due to this new Curriculum students are to undertake the school practice throughout the whole course of Methodology and should be well-prepared to it. To find out whether students feel confidence in their knowledge and have no doubt in its effective usage during their forthcoming school practice (Observed Teaching), the questionnaire was developed and given to the students who were preparing to Observed Teaching having successfully coped with Guided Observation and Teacher Assistantship. The interpretation of the received data of students' expectations according to their future school practice is presented in this article.
\end{abstract}

Key words: Curriculum, trainee teacher, Observed Teaching, Teacher Assistantship, students' expectations, questionnaire.

Problem statement. It goes without saying that investments in public education can contribute to the common well-being, enhance national prosperity, support stability of families and community in general. In the face of economic, environmental and social challenges, education is even more crucial today than it was in the past.

That is why the Ministry of Education and Science of Ukraine together with the British Council in Ukraine in close collaboration with university professors, researchers and school teachers have begun to call for new education policies that target the 
development of broad, transferable skills and knowledge of new generation school teachers of English language.

All this has led to the creation of the Pre-Service Teacher Training (PRESETT) Curriculum at Bachelor's level which has been piloting in ten selected Ukrainian universities (Rivne State University of the Humanities is among them).

Due to this new Curriculum students are to undertake the school practice throughout the whole course of Methodology. During their first year of Methodology learning (terms 3 and 4) students get acquainted with the first phase of their school experience, so called Guided Observation. Once in two weeks they work at school not only observing experienced teachers' lessons but paying their attention to the material which has been learnt at University and how it is used during the lessons, i.e. students can see the connection between theory and practice. Every student has a School Mentor - a high skill teacher who is always ready to help and to explain any problematic situation. To guide and complete their observation of every topic students are to cope with observation tasks. Besides, they describe their visit and observation in feedback which is sent and discussed with their University Tutors.

The second phase of their school experience is called Teacher Assistantship. During it students visit school once a week and their aims are to be teachers' supporters, to try their hand in lesson planning and microteaching. This phase is conducted during the 5th, the 6th and the 7th terms. Students' cooperation with school mentors and university tutors is also continued throughout these terms.

Finally, these two phases lead to the third one which is the conclusive stage of the school practice - Observed Teaching. It takes place in the 8th term and during six weeks students conduct their lessons under the supervision of their School Mentors and University Tutors.

Thus, as it can be seen, students should be really well-prepared to their role of trainee teachers. But nevertheless there is a question whether they themselves think the same.

So, the research aim and objectives of this study is to figure out if the introduced methodology course is considered helpful by students for their forthcoming school practice (Observed Teaching). In order to achieve this aim, the questionnaire was developed and given to the students who were preparing to Observed Teaching having successfully coped with Guided Observation and Teacher Assistantship. Hereafter we present our interpretation of the received data of students' expectations according to their future school practice.

Presenting the main research material. We have created a special questionnaire based on the ELT Methodology Curriculum (Core Curriculum). Focus groups are composed of the $4^{\text {th }}$ year students (21 persons), participants of the Joint Project of the British Council Ukraine and the Ministry of Education and Science of Ukraine guided by moderators. The objective is to find out how respondents evaluate their preparation to the teacher career in the terms related to the topic, whether they feel confident in understanding general concepts of learning and the learner, assessment, professional development, values and other specific issues, perceiving the questions on the scale of "strongly agree", "agree", "not sure" and "disagree".

During the investigation we used a number of qualitative methods in order to get respondents' ideas of the subject matter, some systematic and statistical methods were also used for different purposes.

As it has been pointed above the authors compiled the questionnaire in which factual questions are put together into some tables clearly enough for respondents. Particularly it's a self-administered questionnaire, well compiled, practical and logical. 
As a first step we identified three domains of the questionnaire: Learning and Learners; Teaching, Learning and Assessment and Planning Teaching and Researching. These three domains represent facets of teacher training and build on previous efforts to develop, recognize and organize competencies of teacher. Knowledge and skills are typically measured by specific test questions focused on ELT Methodology and school observation content.

So, the first domain "Learning and Learners" consists of two parts - the first one "Knowing the following helps me during my school practice" and the second "After studying the following I feel I can be more successful during my future observed teaching". Each of the parts proposes eight topics for students to rate (16 in general), e.g. affective factors in language learning (i.e. Knowing affective factors in language learning helps me during my school practice) or different approaches to teaching grammar (i.e. After studying different approaches to teaching grammar I feel I can be more successful during my future observed teaching) and so on.

As it can be noticed from the given bar chart (see Figure 1), we have got the gradation of answers from "strongly agree" and "agree" to "not sure" without any answer "disagree". Answers "strongly agree" vary from $62 \%$ to $14 \%$ and "agree" range from $71 \%$ to $29 \%$ while "not sure" vary $48 \%$ to $9 \%$. Besides, in two bars (Motivational strategies and Techniques for presenting vocabulary) we can see only "strongly agree" (52\% and $33 \%)$ and "agree" (48\% and 67\% respectively).

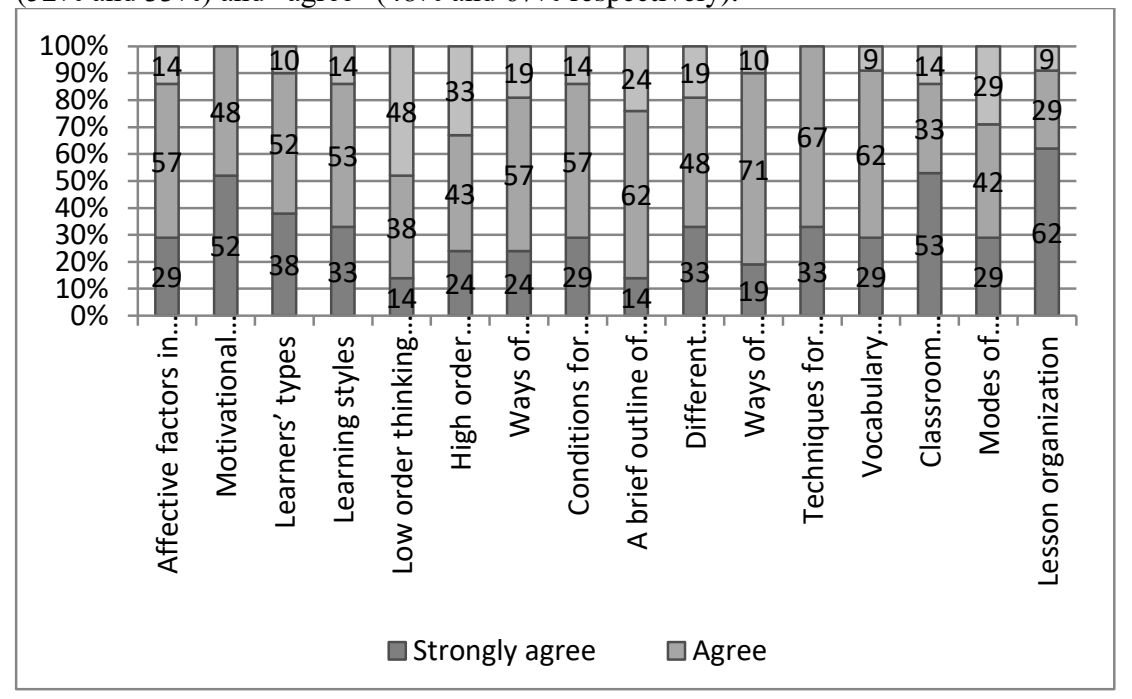

\section{Figure 1. Learning earniand Learners (in \%)}

So, according to the answers in the questionnaire students think that the material from this domain is rather useful and necessary for them to be successful trainee teachers and due to this they do not feel any uncertainty over their future active practice.

The second domain "Teaching, Learning and Assessment" consists of four parts - the first one "Having learned the following I feel I can teach listening during my future observed teaching", the second "Having learned the following I feel I can teach speaking during my future observed teaching", the third "Having learned the following I feel I can teach reading during my future observed teaching" and the fourth "Having learned the 
following I feel I can teach writing during my future observed teaching". Each of the parts proposes four topics for students to rate (16 in general), e.g. possible difficulties while listening (i.e. "Having learned possible difficulties while listening I feel I can teach listening during my future observed teaching") or types of speaking activities (i.e. Having learned types of speaking activities I feel I can teach speaking during my future observed teaching") and so on.

According to the results depicted on the bar chart (see Figure 2), the expectations are even higher than on the previous one. The answers again are only "strongly agree", "agree" and "not sure" without "disagree". Answers "strongly agree" vary from $52 \%$ to $14 \%$, "agree" range from $81 \%$ to $38 \%$ and "not sure" vary from $29 \%$ to $5 \%$. Moreover, four topics in this domain have only two possible answers - "strongly agree" and "agree". They are "Activities for teaching listening skills" - 48\% ("strongly agree") and 52\% ("agree"); "Strategies for developing learners' speaking skills" - 43\% and 57\%; "Types of speaking activities"- $52 \%$ and $48 \%$; "Common problems with reading and how to overcome them" $-48 \%$ and $52 \%$ respectively.

Thus, according to the answers, students feel confidence in their knowledge from this domain and have no doubt that during their observed teaching they can cope with teaching listening, speaking, reading and writing.

And the third domain "Planning Teaching and Researching" consists of two parts the first one "Now I am aware of" (6 topics) and the second "I really feel confident about" (5 topics). Both parts have 11 topics in general, e.g. different models or templates for a lesson plan (i.e. Now I am aware of different models or templates for a lesson plan) or teaching English in primary school (i.e. I really feel confident about teaching English in primary school) and so on.

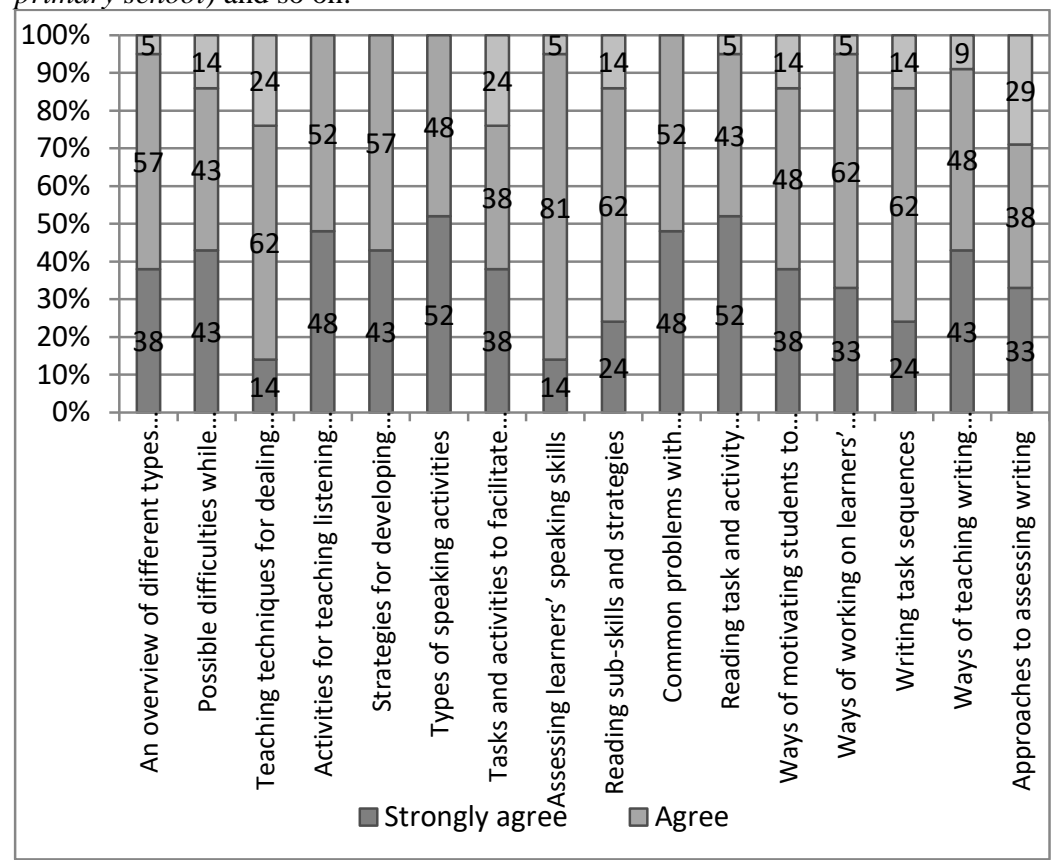

Figure 2. Teaching, learning and assessment (in \%) 
The data in this part of questionnaire (see Figure 3) show that answers vary from "strongly agree" to "disagree" although at the same time the percentage of answer "disagree" is approximately low, from $5 \%$ to $10 \%$. In such a way we can see that only some students anticipate problems with lesson planning, activities and resources for different stages of the lesson, choosing the material and its adaptation, correction and dealing with errors, language assessment and testing. Nevertheless, the answers "strongly agree" (from 14\% to 48\%) and "agree" (from 33\% to 71\%) demonstrate that in general students feel rather strong confidence (from $57 \%$ to $91 \%$ in total) in their knowledge in this domain.

Thus, having looked through the result, we can see that in spite of some doubts, students on the whole demonstrate rather high expectations to the effective usage of the obtained knowledge in this domain.

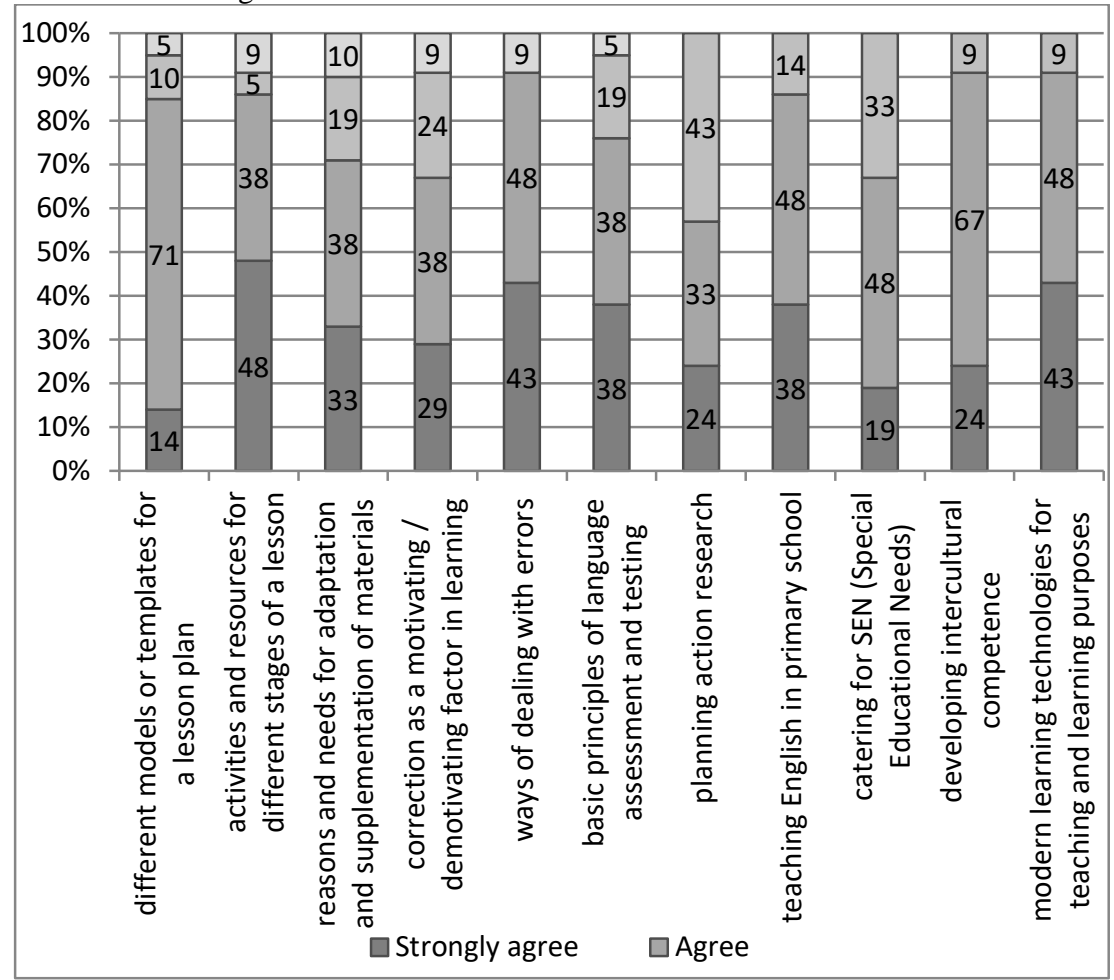

Figure 3. Planning teaching and researching (in \%)

Summarizing the received data from all three domains, we have got the following (see Figure 4). The percentage of students who anticipate their future school practice with a perception that the material they have learnt and experience they have received are very useful, important and necessary and that is why in the questionnaire the answer "strongly agree" was chosen is $34 \%$. The second large group (51\%) is students whose answer was "agree" that means that they are aware of their gained knowledge and are rather sure about their success in teaching. The third part of students who answered "not sure" - which means that they have doubts in their effective lesson conducting - consists of $14 \%$. And the last group whose answer was "disagree", i.e. the students think that they have strong 
hesitation and uncertainty about their active practice at school, is $1 \%$. In such a way, only $15 \%$ of the students are not very sure about the helpfulness of the received knowledge and $85 \%$ have very positive response to their forthcoming practice.

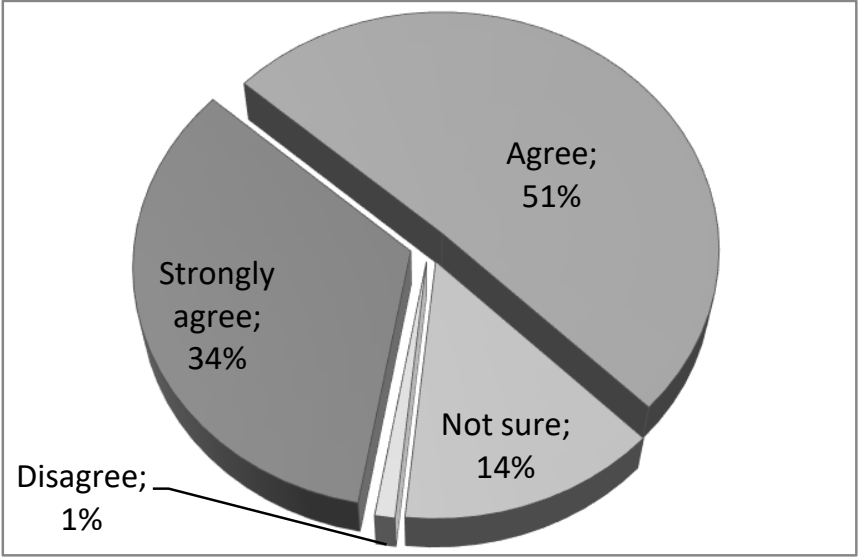

Figure 4. Summary of students' expectations (in \%)

Conclusions and further research prospects. So, having analyzed the answers, we can deduce that the students are rather sure about usefulness, effectiveness and benefit of the received and learnt material from the new methodology course and therefore they are quite optimistic and confident in their readiness for their active phase of school practice. Nevertheless, the results of the questionnaire show that some students have problems with certain topics. That is why we think it necessary to find out the reasons of it and to propose the solution to avoid such misunderstanding of the given material in future. Of course, to make the study completed we are going to compare the received data with the students' answers after the Observed Teaching.

\section{REFERENCES}

Core Curriculum. English Language Teaching Methodology. Bachelor Level. New Generation School Teacher. URL: https://ngschoolteacher.wixsite.com/ngscht/corecurriculum-1 (Accessed 20/03/20)

Brancato G., Macchia S., Murgia M., Signore M., Simeoni G., Blanke K., Körner T., Nimmergut A., Lima P., Paulino R. \& Hoffmeyer-Zlotnik J.H.P. (2006). Handbook of Recommended Practices for Questionnaire Development and Testing in the European Statistical System. European Commission Grant Agreement 200410300002. URL: https:// www.istat.it/it/files/2013/12/Handbook_questionnaire_development_2006.pdf (Accessed 20/03/20) 
Інноватика у вихованні. Випуск 11. Том 1. 2020.

Третьякова Катерина

кандидат філологічних наук, доцент кафедри методики викладання іноземних мов Рівненського державного гуманітарного університету,

м. Рівне, Україна

ORCID: 0000-0001-6821-4652

e-mail:kmvim2012@gmail.com

Бігунов Дмитро

кандидат психологічних наук, викладач кафедри практики англійської мови Рівненського державного гуманітарного університету, м. Рівне, Україна

ORCID: 0000-0001-6100-7765

e-mail: bihunov.d@gmail.com

\section{НОВА ПРОГРАМА 3 МЕТОДИКИ НАВЧАННЯ АНГЛІЙСЬКОЇ МОВИ: ОЧІКУВАННЯ СТУДЕНТІВ ВІД ШКІЛЬНОЇ ПРАКТИКИ}

Анотація. Заклади вищої і середньої освіти знаходяться в активному пошуку нових стратегій та підходів для заохочення й мотивації студентів вчитися. Постійний рух, необхідність швидкої реакції на глобальні зміни в сучасному українському суспільстві спонукають до пошуку нових можливостей у підготовці студентів до самостійного життя. Молодь має бути готовою до викликів сучасності, щоб у майбутньому гідно виконувати роль громадянина, батька, вчителя тощо.

Ось чому нова типова програма методичної підготовки вчителя освітнього ступеня «бакалавр» (у рамках спільного проєкту Міністерства освіти та науки України та Британської Ради в Україні) була створена як важливий, нагальний та необхідний документ і $є$ втіленням нової освітньої політики. Відповідно до нової Програми студенти проходять шкільну практику упродовж усього курсу методики.

3 метою виявлення впевненості студентів у набутих знаннях та розумінні загальних концепцій навчання, оцінювання, професійного розвитку, в оцінці їх особистої підготовки до кар'єри вчителя, ефективності використання набутих знань під час виробничої педагогічної практики в школі, було розроблено опитувальник, в основі якого - найважливіші аспекти нової Типової програми методичної підготовки вчителя освітнього ступеня «бакалавр».

Анкетування було проведено зі студентами, які готувалися до виробничої педагогічної практики й успішно впоралися 3 попередніми етапами шкільної практики, такими як «Кероване спостереження» і «Асистент вчителя».

Аналіз, синтез та інтерпретація отриманих даних, очікувані результати студентів від їх майбутньої шкільної практики представлена в цій статті.

Ключові слова: типова програма, вчитель-практикант, кероване спостереження, асистент вчителя, очікувані результати студентів, опитувальник, студенти.

Стаття надійшла до редакиії 28.02.2020 p. 